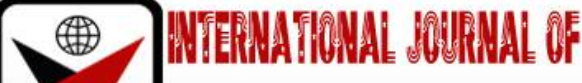

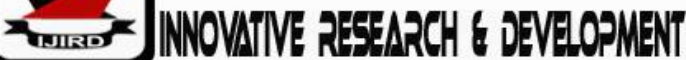

ISSN 2278-0211 (Online)

\section{Pattern of Growth, Socioeconomic Variables and Poverty Reduction in Nigeria: An ARDL Analysis}

\author{
Fashanu Felix Adeniyi \\ Lecturer, Department of Economics, McPherson University, Nigeria \\ Kasali Taofeek Aremu \\ Principal Lecturer, Department of Business and Management Studies \\ Moshood Abiola Polytechnic, Nigeria
}

\begin{abstract}
:
In view of the failure of economic growth that characterized most of the developing economies to result in substantial reduction in their poverty incidences, several attempts have been advanced the missing link between these variables. This study, therefore, investigated the impact of patterns of growth and socioeconomic variables on poverty reduction in Nigeria from 1981-2018. To achieve this, the study applied Autoregressive Distributed Lag (ARDL) technique to analyse time-series data sourced from Central Bank of Nigeria (CBN), National Bureau of Statistics (NBS) and World Development Indicators (WDI). The findings revealed that for both the long-run and short-run, growth in RGDP per capital emanating from agriculture (PCA) and industry (PCI) as well as inequality (INQ), inflation (INF), human capital (HC) and unemployment (UMP) have significant long-run relationship with poverty reduction at various levels of significant. Further to this, the short-run estimated results reveal that the lagged values of poverty reduction, pattern of growth, inequality, inflation, unemployment and human capital development have significant impact on poverty reduction for the present period. The study, therefore, concluded that even though all the variables have longrun and short-run relationship with poverty reduction in Nigeria, only the results for the variables PCA, PCI, INQ, INF, $H C$ and UMP are statistically significant. Of all these variables that are statistically significant, growth in PCA and/or reduction in INQ have the highest potentials of achieving poverty reduction in Nigeria. Therefore, any policy formulation that is aimed at reducing poverty incidence in Nigeria must provide support to the agriculture sector and address the issue of income distribution.
\end{abstract}

Keywords: Poverty reduction, pattern of growth, socioeconomic variables, inequality and human capital development

\section{Introduction}

The menace of poverty has consistently been in the forefront of policy discussions in all economies, irrespective of their levels of development. In fact, it has since taken a global dimension in terms of academic researches and government social expenditures. While the advanced economies grapple with how to deal with relative poverty within their various economies, the developing economies have to, in addition to relative poverty, consider the reduction in absolute poverty level. This assertion is evidenced in the priority given to poverty reduction in both the Millennium Development Goals (MDGs) and its newly advocated replacement, Sustainable Development Goals (SDGs) (NBS, 2016). According to Ravallion (2016), all global efforts geared towards the achievement of poverty reduction has always involved making a choice between two policies: making policies that reallocate resources away from the rich to the poor; implementing effective policies that are aimed at reducing global poverty.

However, in spite of the general consensus on the need for poverty reduction, either relative or absolute poverty, opinions have differed on how best to achieve this macroeconomic goal. It was formally advocated in the literature that there is a positive nexus between growth in a nation's real GDP and poverty reduction (Loayza and Raddatz, 2010; Montalvo and Ravallion, 2009; Ferreira, Leile and Ravallion, 2007; Christiansen, Demery and Kuhi, 2010; Chuham-Pole, 2014 and Christiansen and Kamiviski, 2015). This claim posits that rising in real GDP will bring about a reduction in a nation's poverty incidence. Empirical evidences have, however, revealed that the tremendous growth experienced by many of the developing economies, including Nigeria, has widened the incidence of poverty in these economies. These results advise this study's believe that while growth in real GDP is necessary for poverty reduction inany economy, it is not a sufficient condition. There are other factors that must be considered in addition to growth in real GDP. Ferreira et al (2007) andChuham-Pole (2014) opined that apart from economic growth, the pattern or sources of growth also matters in achieving relative and absolute poverty reduction in any given economy. While growth from some sectors was found to be pro-poor in their respective studies, others were found to be pro-rich. Further to this, Igor (2016) found from his study on Brazil that in addition to economic growth and pattern of growth, government social expenditure and some 
socioeconomic variables also play majorroles in achieving poverty reduction in any given economy.In agreement with this assertion, Ravallion (2016) found that the real GDP does not reveal to us anything about how the growth in income is distributed. The extent of poverty reduction is dependent upon both aggregate revenue and its distribution (Ravallion, 2016). By this contribution, Ravallion (2016) has added the roles of inequality in poverty reduction.

From the Nigerian economy, however, successive governments have adopted several policy options towards achieving the goal of poverty reduction. In its bid to alleviate poverty, the government of Nigeria recognized the need to create a conducive environment for investment. It initiated and launched the Poverty Alleviation Programme (PAP) within the framework of Budget 2000. The programme was designed to provide employment for 200,000 people and the sum of N10 billion was set aside for it. The programme was implemented in every state of the Federation and it provided jobs for 214,367 people who were paid stipends of N3, 500 per month. In January, 2001, the Poverty Alleviation Programme was phased out and replaced with the National Poverty Eradication Program (NAPEP), which was responsible for coordinating and monitoring the activities of the core Poverty Eradication Ministries and Agencies (Kasali, Ahmad and Lim, 2016)

The major policy thrust of the National Poverty Eradication Program (NAPEP) is to eradicate absolute poverty in Nigeria by the year 2010. This is based on the premise that about 70 percent of Nigerians live below the poverty line. NAPEP has provided strategies for the eradication of absolute poverty by streamlining and rationalization of existing poverty alleviation institutions; and coordinated implementation and monitoring of relevant schemes. As the government's response to the worsening condition of the poor continued through expending heavily towards the eradication of poverty, the situation remains as poverty conditions continue to escalate (Kasali et al, 2016).

The trends in both economic growth and poverty rate in Nigeria have, however, shown some exceptions to the assertion that economic growth tends to lead to poverty reduction in Nigeria. Figure1 shows that RGDP had grown consistently during the period of study, with the exception of the period 2013 to 2017 when the economy experienced some depressions. Within this same period, there was no significant impact of growth in the nation's real GDP on poverty reduction in Nigeria. In the average, while the RGDP grew at an average rate of 3.8\% from 2010 to 2018, poverty rate also grew at an average rate of $0.06 \%$ (Central Bank of Nigeria (CBN), 2019). From these trends, therefore, the question arises as to why the sustained growth in economy overtime left little or no impact on poverty reduction in Nigeria. In response to this question, Ferreiraet al (2007) and Chuham-Pole (2014) were of the opinion that while economic growth is necessary for achieving pro-poor growth, the pattern or source of growth also matters. According to Chuham-pole (2014), other social factors must also be considered in determining the effect of growth on poverty reduction. These factors were later identified by Igor (2016) as government social expenditures and socioeconomic variables like inflation, income inequality, unemployment rates and human capital. It is for this reason that this study attempts to investigate the nexus between socioeconomic variables and poverty reduction.

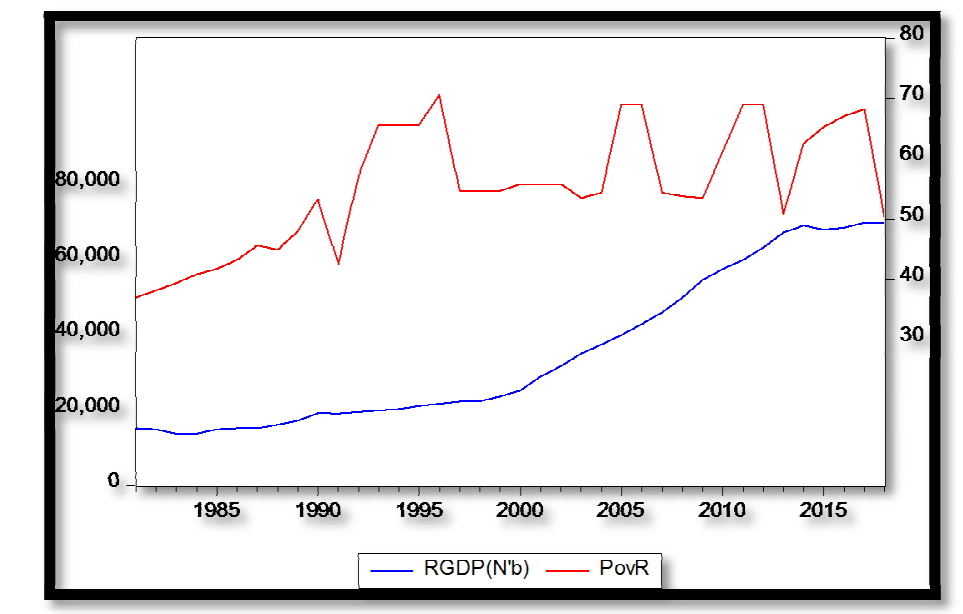

Figure1: The Trend in RGDP and Poverty Rate in Nigeria (1981-2018) Source: Authors' Computation Using Eview 10

Figure 2 shows that the per capita income (PCRGDP) in Nigeria has grown consistently between 1981 and 2018 at an average growth rate of $4 \%$. On the other hand, however, poverty (Povrate) has not experienced any significant reduction with the exception of the period between 1999 and 2005. In the average poverty has continued to grow at an average rate of $1 \%$ between 1985 and 2018. Could this be as a result of growth emanating from sectors that are dominated by the few rich people? Which sector is, therefore, likely to have a higher elasticity of poverty reduction, and hence has the greatest propensity for achieving a pro-poor growth in Nigeria's per capita income? It is for this reason that this study seeks to investigate the impact of sectoral composition of economic growth on income poverty reduction in Nigeria. 


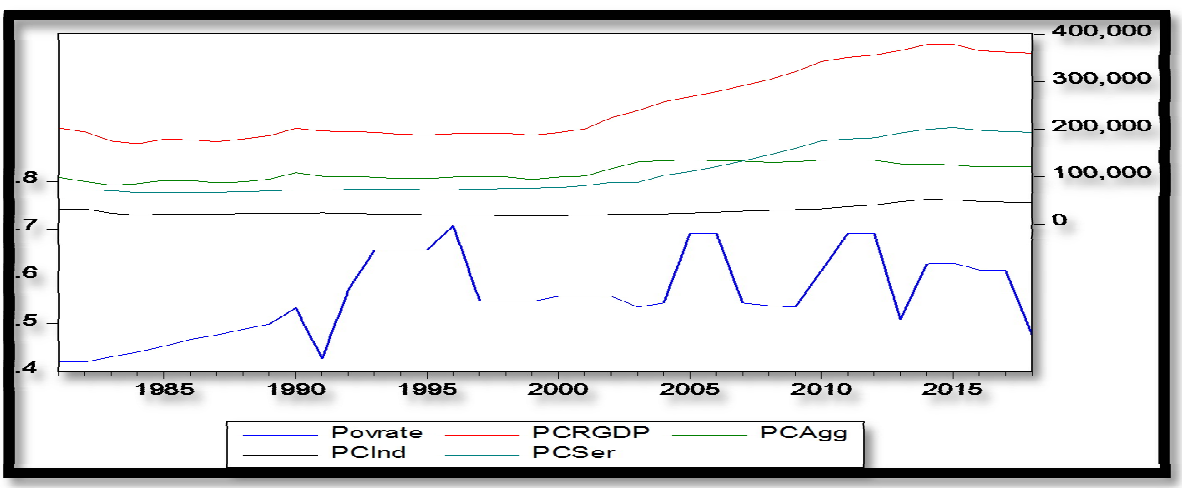

Figure 2: Growth in Per Capita Income, Sectoral Per Capita Income and Poverty Reduction Source: Authors' Computation Using Eview 10

Figure 3presents the pattern and trend in the growth of inflation, inequality, unemployment and human capital. The gini coefficient, which measures the income inequality in Nigeria reveals consistent rise between 1981 and 2000 , thus implying that growth has only favored the rich at the expense of the majority poor. However, a little drop was noticed from 2000 to 2005 and 2015 to 2018 . Further still, in spite of the efforts of various governments through their respective macroeconomic policies, not much was achieved in improving inflationary rate and unemployment. However, only human capital seems to have experiencing some improvements. Could these unfavorable trends be responsible for why the sustainable growth in the nation's real GDP has left little or no impact on poverty reduction in Nigeria? It is in view of all these, therefore, that this study investigates the impact of pattern of growth and socioeconomic variables on poverty reduction in Nigeria for a period between 1981 and 2018.

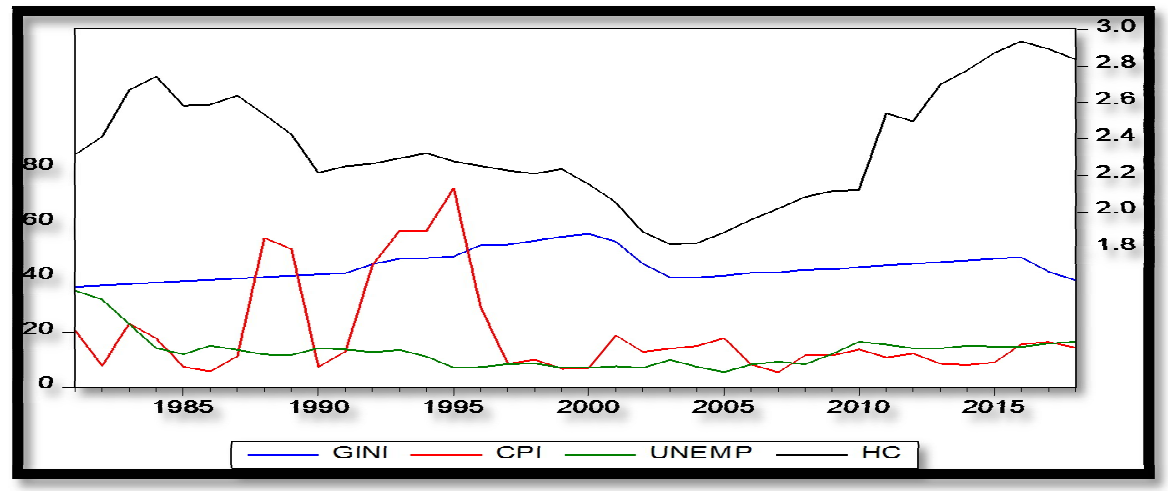

Figure 3: The Trends and Patterns of Growth in Inequality, Inflation, Unemployment and Human Capital Source: Authors' Computation Using Eview 10

This study is to cover the period from 1981 to 2018. The choice of this period is to allow for a consideration of the period of Structural Adjustment Program (SAP) and GDP rebasing in Nigeria. It is also expected that this study will be beneficial to the Nigerian government through the provision of empirically based recommendations that will aid good policy formulation. It will also be beneficial to researchers and investors who are major stakeholders in the Nigerian economy. Along with the introductory section, this study is structured into five sections. Section two presents the literature review, while section three is dedicated to methodology and theoretical framework. Findings and discussion, conclusion and recommendation shall be presented in sections four and five respectively.

\section{Literature Review}

With growth referred to in the literature as a rise in an economy's GDP, real or nominal, overtime, sectoral composition of output is considered to be the decomposition of total output on the basis of the contributions of each economic sector to overall productivity. The main economic sectors consist of the primary (agriculture) sector, the secondary (industrial) sector and the tertiary (service) sector. The pattern of growth theory states that the sectoral or geographical composition of all economic activities that culminate in the total growth of the economy. It, therefore, refers to the value of the shares of each of the sectors to the overall growth in the nation's real GDP overtime.

Socioeconomic variables are regarded as factors of a social and economic nature which affects human's status within an economy (Monash Business School, 2020). It includes such variables like inequality, inflation, human capital and unemployment which are expected to determine the ability of a person to meet his basic social needs (Igor, 2016).

Poverty, on the other hand, has been a difficult concept to define because of its nature and the multi-dimensional effects of it on individuals and economies. Poverty means lack of basic necessities. It widens the gap between individuals and creates economic and social inequality. When people are deprived of some basic needs, they are categorized as being poor. The concept of poverty line is based on what an individual would need to make a moderate (not lavish) living. In the literature, poverty has been described as a complex and multidimensional problem. 
Moreover, poverty can also be described as a state of deprivation or lack of resources to meet the basic needs. It shows the lack of essential facilities caused by inadequate income. In 2002, the World Bank Group described poverty as a fluid concept that has many definitions. It has social, cultural, economic, political and more recently environmental dimensions. It can be seen as hunger, lack of shelter or being sick and not being able to afford to see a doctor (World Bank, 2014). Poverty is, not being able to afford to go to school and not knowing how to read, not having a job; fear for the future; living one day at a time, losing a child to illness brought about by unclean water; powerlessness; lack of representation and freedom. Poverty means lack of income and productive resources sufficient to ensure sustainable livelihood. It manifests in hunger and malnutrition; ill health; limited or lack of access to education and basic services; increased morbidity and mortality from illness; homelessness and inadequate housing; social discrimination and social exclusion; it is also characterized by lack of participation in decision making and in civil, social and cultural life (World Bank, 2014).

In view of this multi-dimensional nature, this study considers economic poverty which shall be defined as the economic conditions which prevents the people from enjoying certain minimal level of health, education, food, shelter and other basic needs because of paucity of financial opportunities (World Bank, 2014). Hartwell (1972) attempted to draw out the central roles of poverty in the study of economics when he wrote that economics is essentially the study of poverty. To further lend credence to this assertion, Schultz (1981) opined that 'most people in the world are poor. If we knew the economy of being poor, we would know much of the economics that really matters'. This income poverty has been measured severally in the literature using any of headcount (number of people living below poverty line), poverty gap or squared poverty gap (Chuhamn-Pole, 2014).

The theoretical underpinning for the nexus between socioeconomic variables and poverty reduction has been located within the purview of pro-poor and structural change growth theories (Anand, Miahra and Peiris, 2013).

While some empirical supports were found in the literature for this theoretical relationship in developed and some emerging economies, studies from developing economies have revealed conflicting results (Ravallion, 2010; Dursun and Ogunleye, 2016 \&Gangas, 2017). Findings from other empirical studies have also revealed that poverty reduction does not depend on the pace of growth alone, but much more also on the pattern of growth (Loayza and Raddatz, 2010; Montalvo and Ravallion, 2009; Ferreira et al 2007; Christiansen, Demery and Kuhi, 2010; Christiansen and Kamiviski, 2015).Chuham-Pole (2014) opined that the pattern of growth is, however, more significant because of the size of the sectors and differences in the participations of the poor in both the processes leading to the production of, and the benefits from the opportunities. Their study further revealed that for Africa and Sub-Sahara Africa, poverty reduction emanated from growth resulting from both the agriculture and services sectors, as against the rest of the world where property reduction was from growth in the manufacturing and service sectors respectively. However, the country-specific studies of two of the six sub-Sahara Africa countries earlier studied by Chuham-Pole (2014) revealed the relative importance of the agriculture sector (Hill \&Tsehaye, 2014; World Bank, 2014 \& 2019). In Ethiopia, for instance, an annual growth of $8 \%$ in its per capita income resulted in a drastic fall in the nation's poverty rate. This was further found to have resulted from growth in the agriculture sector (Hill \&Tsehaye, 2014). It was for this reason that Chuham-Pole (2014) suggested that further studies be carried out on each of the countries constituting the Sub-Saharan nations.

Extending this study further, Igor (2016) was of the view that while the structure of growth impacts significantly on poverty reduction in most economies studied, this is not a sufficient condition for poverty reduction. He opined that other factors like government social expenditure and other auxiliary covariates like inequality, unemployment, inflation and human capital also impact significantly on poverty reduction. To investigate this from Brazil, Igor (2016) adapted the model by Ravallion and Chen (2007) by incorporating government social expenditure and auxiliary covariates to analyse panel data for a period between 2002 and 2009. His findings revealed that inequality reduction and increase in human capital attainment were the most important factors in achieving poverty reduction in Brazil. Government social expenditures were also found to have played a marginal role through education and health. However, federal cash transfers were found not to have provided any significant effect.

Several studies have been carried out from the Nigerian economy on various issues relating to economic growth, pro-poor and inclusive growth (Becker, 1995; Ijaiya, Ijaiya, Bello, and Ajayi, 2011; Ugwu, 2012; Ebong and Ogwunike, 2013; Ogbeide and Agu, 2015; Chikolu, 2016; Adelakun J. 0, 2018; Obayori, Udeorah and Aborh, 2018; Ayeni and Omobude, 2018; Adekoya, 2018; Ogunleye, Owolabi, Sanyaolu and Lawal, 2018; Sylvester and Obayori, 2018; EwubareOkpani, 2018 and Olopade, Okodua, Oladosun and Asaleye, 2019). Ijaiya, Ijaiya, Bello, and Ajayi (2011) had earlier found that in Nigeria, while economic growth is essential for poverty reduction, results from empirical studies were not significantly in support of this assertion. It was only the initial level of economic growth that favoured poverty reduction. They were of the opinion that this could be because growth resulted from the rich-dominated sectors. EwubareOkpani (2018) applied the OLS technique to investigate how poverty, unemployment and life expectancy impact on inequality in Nigeria. They concluded from their findings that increase in both poverty and unemployment can lead to a significant increase in income inequality. Their Pair wise causality test results further revealed a bi-directional causality between poverty and inequality over the period of the study. Ayeni and Omobude (2018) also studied the effects of education expenditure on economic growth in Nigeria. With the application of Autoregressive Distributed Lag (ARDL) to time series data for a period from 1987 to 2016, they found that while the recurrent education expenditure is significant and positively correlated to economic growth, capital expenditure is not. Ogunleyeet al (2018) found a positively significant impact of human capital on economic growth with the application of OLS technique for their analysis. However, with the application of Generalised Method of Moment (GMM), Sylvester et al (2018) found a positive, but not significant relationship with economic growth. 
In view of the study's review of literature, we found that several studies have been carried out from the Nigeria economy on the relationship between economic growth, poverty reduction and each of the socioeconomic variables respectively. However, we found that to the best of our knowledge, no study has been able to investigate the nexus between pattern of growth, an aggregated socioeconomic variables and poverty reduction in Nigeria. We are, therefore, encouraged to investigate the impact of pattern of growth and socioeconomic variables on poverty reduction in Nigeria.

\section{Methodology}

Empirical researches on the effects of economic growth on poverty reduction and the nexus between sectoral composition of growth in per capita income and poverty reduction have been conducted by several researchers for the developed, emerging and developing economies. Analysis of an extension of these studies to include the impact of aggregated socioeconomic variables on poverty reduction is as recent a phenomenon as the study on sustainable development growth (SDG). This explains why there is a paucity of well-developed modeling framework in this area of study. The most recent research in this area was carried out by Igor (2018) who adapted the Ferreira model as applied by Ferreira, Leite and Ravallion, (2007), Montavo and Ravallion (2019) and Chuham-Pole (2014). His adapted model is expressed as:

$$
\Delta \ln P_{i t}=\beta_{i t}^{A} S_{i t-1}^{A} \Delta Y_{i t}^{A}+\beta_{i t}^{I} S_{i t-1}^{I} \Delta Y_{i t}^{I}+\beta_{i t}^{S} S_{i t-1}^{S} \Delta Y_{i t}^{S}+\sigma_{i t}^{J} X_{i t}^{J}+\varphi_{i t}^{k} Z_{i t}^{k}+\pi_{i}^{J}+\cup_{i t} \text { eq } 1
$$

Where $\Delta \ln P_{\text {it }}$ measures poverty reduction in State or Municipal i at time $t$.

A, I and S denote the various sectors (Agriculture, Industry and Service).

$\mathrm{YI}_{\mathrm{it}}$ represents the real GDP per capita of the sector $\mathrm{j}$ in State/Municipal I at time $t$.

The error term includes a state fixed effect $\left(\Pi_{I}\right)$ and a time varying effect $\left(U_{i t}\right)$, both of which might be auto correlated.

$\mathrm{Si}_{\mathrm{t}-1}$ represents share of sector $\mathrm{j}$ in the total real GDP per capita for State/Municipal i in time $\mathrm{t}$.

$\mathrm{X}$ is a covariate that represents government expenditures disaggregated with J representing capital transfers and federal transfers.

$\mathrm{Z}$ represents the socioeconomic variables, as ' $\mathrm{k}$ ' stands for each of inequality, inflation, unemployment rate and human capital.

Since the interest of this study is to investigate the impact of the pattern of growth and socioeconomic variables $\left(\mathrm{X}^{J}\right)$ on poverty reduction, equation 1 above shall, therefore, be modified as follows:

$$
\Delta \boldsymbol{l n} \boldsymbol{P}_{t}=\sum \beta_{t}^{j} S_{t-1}^{j} \Delta Y_{t}^{j}+\sum \varphi_{t}^{k} Z_{t}^{k}+\cup_{t} \mathbf{e q} 2
$$

Note that the introduction of the share of sector $\mathrm{S} J$ in equation 2 is to correct the faulty and unrealistic assumptions that all the sectors impact on poverty reduction in the same proportion (Ravallion and Datt, 1996). Ravallion and Datt (1996) proposed this model as a way of taking into consideration the share of each sector 'J' to the overall growth of the economy. This is based on their assumption that each sector's impact on poverty reduction should be a factor of the sector's size (Ravallion and Datt, 1996 and Ferreira et al, 2007). Further still, Ravallion and Datt (1996) used the lagged values of the sector's share to reflect their expectation that the share in the previous period will only affect poverty reduction.

In order to reduce the variability or skewness of the data employed, and make them conform more closely to the normal distribution, the study takes the log transformation of the data. Also since the study is considering the growth effects of our variables of study, we, therefore, take the first differences of all the data employed. Taking all these into consideration, the study expands equation 2 to reflect each of the three sectors and four socioeconomic variables of study to obtain the study's model specification in equation 3.

Where,

$$
\begin{gathered}
\Delta \ln P_{t}=\beta_{1}^{A} S_{t-1}^{A} \Delta Y_{t}^{A}+\beta_{2}^{I} S_{t-1}^{I} \Delta Y_{t}^{I}+\beta_{3}^{S} S_{t-1}^{S} \Delta Y_{t}^{S} \beta_{4} \Delta I N Q_{t}+\beta_{5} \Delta I N T_{t}+ \\
\beta_{6} \Delta U N E M P_{t}+\beta_{7} \Delta H C_{t}+\varepsilon_{t} \text { eq. } 3
\end{gathered}
$$

$\Delta \ln P_{t}$ stands for growth in poverty rate;

$\mathrm{A}, \mathrm{I}$ and $\mathrm{S}$ denote the various sectors (Agriculture, Industry and Service).

$\mathrm{YI}_{\mathrm{t}}$ represents the real GDP per capita of the sector $\mathrm{j}$ in time $\mathrm{t}$.

The error term is expressed as $\varepsilon_{t}$

$\mathrm{Si}_{\mathrm{t}-1}$ represents share of sector $\mathrm{j}$ in the total real GDP per capita in time $t$.

INQ represents income inequality; INF stands for inflation; UNEMP is the unemployment rate, while HC represents human capital.

The a priori expectations of the study regarding the behavior of the independent variables' estimated parameters are:

\section{$\beta_{4}, \beta_{5}$ and $\beta_{6}<0$ and $\beta_{1}, \beta_{2}, \beta_{3}$ and $\beta_{7}>0$}

This implies that the variables income inequality, inflation and unemployment should be negatively related to poverty reduction or eradication. That is any increase in any of this further increases the incidence of poverty, thus leading to decrease in poverty eradication. However, increase in pattern of growth and human capital is expected to be positively related to poverty reduction or eradication. It is expected that any improvement in any of these variables should lead to a reduction in the incidence of poverty.

Measurement of the incidence of income poverty has been done severally in the literature because of the challenges to researchers on multifaceted nature of poverty. In providing what was considered as a more acceptable measure of poverty, Ravallion (2016) differentiated between absolute and relative poverty. He considered absolute poverty as the measurement of the number of people living below a globally set standard of living. Relative poverty, on the other hand, is considered to include all the people living below the standard of living set by the country of their residence 
(Ravallion, 2016). He concluded, therefore, that whether in absolute poverty or relative poverty, the major ingredient of poverty measurement is the consideration of household's consumption or income. In view of all these, three different consumption-based methods have been applied severally. These are headcount index, poverty gap and squared poverty gap (Ravallion, 2010; Ferreira et al, 2007; Loayzaet al, 2010 and Chuhum-Pole, 2014). This study therefore, measures poverty incidence by using the headcount gap for reason of data availability and accessibility. The poverty gap is measured as the proportion of the population living under $\$ 1.50$ per day. Output growth, on the other hand, is disaggregated into three sectors (agriculture, industry and services), where each sector's output is the share of the sector from the total real GDP per capita.

In conformity with the general trend in the literature (Igor, 2016), the study proxies income inequality and inflation with GINI coefficient and Consumer Price Index (CPI) respectively. Unemployment rate is also captured as the percentage of unemployed people to total population. Human capital has, however, been proxied by different researchers using different factors. Igor (2016) used the addition of education capital expenditures and total enrolment of people from 25 years and above. This study considers the enrolment figure as improper because it is not all those that enrolled for education that eventually attended and finished, especially in developing countries like Nigeria. Also a student's participation in productive activities is the way to measure his effectiveness. Organisation for Economic Cooperation and Development (OECD) identified human capital measurement as closely related to investment in education (Kwon, 2006). Other authors, however, proxied human capital using total government expenditure in education and health (Becker, 1995; Olopadeet al 2019 and Obayoriet al, 2018). For the above reasons, therefore, this study shall proxy human capital using government expenditures on education and health.

To establish the long-run relationship between pattern of growth, socioeconomic variables and poverty, equation 3 shall be estimated using Augmented Distributive Lag (ARDL) technique to analyse time series data sourced from the Central Bank of Nigeria (CBN, 2019), World Development Index (World Bank, 2019) and Nigeria's National Bureau of Statistics (NBS, 2012; 2019).

For our pre-estimation test, the study carries out the unit root test to determine the stationarity of the variables of study. It is necessary to note that while the ARDL techniques can be used to estimate data with unit root, it is only appropriate even for variables combinations of stationarity at levels $1(0)$ and at first difference 1(1). This explains the reason for the unit root test. The study shall also conduct a bond test to establish the presence of a long-run relationship between the dependent and independent variables.

For the empirical analysis, the study employs the ARDL techniques to estimate the variables of the study. The application of ARDL technique in this study is hinged on its advantage over Ordinary Least Square method (OLS). The ARDL technique does not require variables to be $1(0)$, but is also applicable even to variables that are mixtures of levels $1(0)$ and first difference 1(1). It also allows for the estimation of both the short-run and long-run relationship between the variables simultaneously.

\section{Findings and Discussions}

As a form of pre-estimation test, this study carried out a unit root test using the Augmented Dickey-Fuller to test for stationarity level of the variables employed. The result is shown in Table 1 below.

\begin{tabular}{|c|c|c|c|c|c|}
\hline \multirow{2}{*}{ Variables } & \multicolumn{2}{|c|}{ Levels } & \multicolumn{2}{c|}{ First Difference } & \multirow{2}{*}{ Decision } \\
\cline { 2 - 5 } & ADF & CRI. VALUE & ADF & CRI. VALUE & \\
\hline P & -2.84974 & $(-2.943427)^{* *}$ & - & & $1(0)$ \\
\hline PCA & $-2.110847^{*}$ & $(-4.234972)$ & - & & $1(0)$ \\
\hline PCI & $-2.710319^{*}$ & $(-4.234972)$ & - & & $1(0)$ \\
\hline PCS & $-1.438067^{*}$ & $(-4.309824)$ & - & & $1(0)$ \\
\hline INQ & -2.49911 & $(-2.943427)^{* *}$ & - & & $1(0)$ \\
\hline INF & -2.89340 & $(-2.945842)^{* *}$ & - & & $1(0)$ \\
\hline UNEMP & -4.62861 & $(-3.62103)^{*}$ & - & & $1(0)$ \\
\hline HC & -1.134218 & - & -4.567713 & $(-3.699871)^{*}$ & $1(1)$ \\
\hline
\end{tabular}

Table 1: Summary of Stationarity Test

Note: * Significant at 1\%; ** Significant at 5\%; *** Significant at 10\%

Source: Authors' Computation Using Eview 10

The results revealed that variables such as Poverty Rate (P), Sectoral share of per capita income (PCA, PCI and PCS), Inflation (CPI), Unemployment (UNEMP) and Inequality (GINI) were found stationary at levels. However, Human Capital was found to be stationary at first difference. This further justifies the application of ARDL for study's analysis. Thereafter, the study examined the long-run relationship testing between the dependent and independent variables using ARDL bound test before the short-run and long-run estimates. This is necessitated by the desire to ensure a convergence in the model, to prove there is a long run relationship among the series. Thus, the derivation of the long-run relationship between poverty rate and the socioeconomic variables is presented in Table 2 below. 


\begin{tabular}{|c|c|c|}
\hline \multicolumn{2}{|c|}{ Critical Value Bounds } & 7.823496 \\
\hline F-statistics (POVR / PCA PCI PCS INQ INF HC UNEMP) & 7 \\
\hline Significance & I0 Bound & I1 Bound \\
\hline $10 \%$ & 1.92 & 2.89 \\
\hline $5 \%$ & 2.17 & 3.21 \\
\hline $1 \%$ & 2.73 & 3.90 \\
\hline
\end{tabular}

Table 2: Long-Run Relationship Using ARDL Bound Test (2,2,0,0,2,2,1,2)

Source: Authors" Computation using E-view 10

The F-statistics of the estimated normalized equations $\left(\mathrm{F}_{\mathrm{arb}}=7.823496\right)$ is greater than the lower and upper critical bound at $1 \%$ significance level. It implies that the null hypothesis of no long-run relationship is rejected at $1 \%$ significance level, and that there exists a long-run relationship between sectoral shares of PCI, poverty reduction, inflation, inequality, human capital and unemployment rate in Nigeria. Having established the existence of a long-run relationship between the dependent and independent variables, the study proceeded to estimate the nature of this relationship using ARDL technique.

The ARDL approach automatically choose the lag length on all variables as the model was set at two to ensure sufficient degree of the freedom based on automatic selection of Akaike Information Criterion. The results of both the long-run and the short-run estimates are presented in Table 3.

\begin{tabular}{|c|c|c|c|}
\hline \multicolumn{4}{|c|}{ Dependent Variable:dlnPR } \\
\hline \multicolumn{4}{|c|}{ Selected Model: ARDL $(2,2,0,0,2,2,1,2)$} \\
\hline \multicolumn{4}{|c|}{ Sample: 19812018} \\
\hline \multicolumn{4}{|c|}{ Long-Run Estimates } \\
\hline Variable & Coefficient & Std. Error & t-Statistic \\
\hline $\mathrm{SA}_{\mathrm{t}-1} \mathrm{dln} P C A$ & 11.25523 & 2.455266 & $(4.584119)^{*}$ \\
\hline $\mathrm{SI}_{\mathrm{t}-1} \mathrm{dln} \mathrm{PCI}$ & -6.560051 & 2.917808 & $(-2.248281)^{* *}$ \\
\hline $\mathrm{SS}_{\mathrm{t}-1} \mathrm{dln} P C S$ & 0.368618 & 1.674535 & $(0.220132)$ \\
\hline $\mathrm{dln} I N Q$ & -0.805849 & 0.285926 & $(-2.818384)^{* *}$ \\
\hline dlnINF & -0.104202 & 0.016403 & $(-6.352516)^{*}$ \\
\hline $\mathrm{dlnHC}$ & 0.323796 & 0.065686 & $(4.929492)^{*}$ \\
\hline dlnUMP & -0.195461 & 0.061434 & $(-3.181616)^{*}$ \\
\hline \multicolumn{4}{|c|}{ Short-Run Estimates } \\
\hline $\operatorname{dln} P R(-1)$ & -0.521824 & 0.181355 & $(-2.877916)^{*}$ \\
\hline $\operatorname{dln} P R(-2)$ & -0.804073 & 0.200950 & $(-4.001368)^{*}$ \\
\hline $\mathrm{SA}_{\mathrm{t}-1} \mathrm{~d} \ln \mathrm{PCA}$ & 10.35615 & 3.139573 & $(3.298586)^{*}$ \\
\hline $\mathrm{SA}_{\mathrm{t}-1} \mathrm{~d} \ln \mathrm{PCA}(-1)$ & 4.144405 & 3.562933 & $(1.163200)$ \\
\hline$S A_{t-1} d \ln P C A(-2)$ & 11.67908 & 2.889553 & $(4.041830)^{*}$ \\
\hline $\mathrm{SI}_{\mathrm{t}-1} \mathrm{~d} \ln \mathrm{PCI}$ & -15.25866 & 6.662718 & $(-2.290156)^{* *}$ \\
\hline $\mathrm{SS}_{\mathrm{t}-1} \mathrm{~d} \ln P C S$ & 0.857405 & 3.888021 & $(0.220525)$ \\
\hline dlnINQ & -0.085900 & 0.441479 & $(0.194574)$ \\
\hline $\operatorname{dln} I N Q(-1)$ & -0.802727 & 0.512846 & $(1.565238)$ \\
\hline dlnINQ(-2) & -0.985775 & 0.741541 & $(1.329361)$ \\
\hline dlnINF & -0.108933 & 0.025556 & $(4.262692)^{*}$ \\
\hline $\operatorname{dlnINF}(-1)$ & -0.032704 & 0.021488 & $(1.521940)$ \\
\hline $\operatorname{dln} I N F(-2)$ & 0.100734 & 0.025852 & $(3.896745)^{*}$ \\
\hline $\mathrm{dlnHC}$ & 0.470237 & 0.128371 & $(3.663118)^{*}$ \\
\hline $\operatorname{dlnHC}(-1)$ & 0.282912 & 0.099266 & $(2.850054)^{* *}$ \\
\hline dlnUMP & -0.120485 & 0.063115 & $(-1.908997)^{* * *}$ \\
\hline dlnUMP(-1) & -0.146428 & 0.06217 & $(-2.331034)^{* *}$ \\
\hline dlnUMP(-2) & -0.187728 & 0.078395 & $(-2.394652)^{* *}$ \\
\hline ECT $(-1)$ & -2.325998 & 0.226370 & $(-10.27702)^{*}$ \\
\hline R-Square & 0.811784 & F-stat & $(3.833819)^{*}$ \\
\hline Adj. R-Square & 0.600041 & & \\
\hline
\end{tabular}

Table 3: Results of Estimated ARDL Model

Note: *Significant at 1\%; ** Significant at 5\%; *** Significant at $10 \%$

Source: Computed by the Authors' Using E-View 10

It should be noted at this point that the results of the estimated parameters $\beta_{1}-\beta_{3}$ expressed in Table 3 are not the true measures of their elasticities of poverty reduction. This is because the specification of the model of study (Eq. 3) considers the weighted sectoral share of the sectors respectively (Igor, 2016), and not the actual share in the RGDP per capita. 
The results presented in Table 3 revealed the relative importance of each variable of studyin achieving the sustainable development goal of poverty alleviation or reduction in Nigeria. The table presents the relationship between poverty reduction and the variables of study in both the long-run and short-run. Long-run estimates of the coefficients revealed that the growth in RGDP per capital emanating from agriculture (PCA) and industry (PCI) as well as inequality (INQ), inflation (INF), human capital (HC) and unemployment (UMP) have significant long-run relationship with poverty reduction at various levels of significant. Growth from agriculture sector has significantly (1\%) positive impact on poverty reduction in the long-run, thus implying that any increase in the share of agriculture to economic growth enhances poverty reduction. The result for human capital development (HC) also revealed a significantly positive long-run relationship at $1 \%$ significant level. This implies that any increase in HC will result in reduction in poverty incidence. On the other hand, however, the study found that growth from the industrial sector (PCI), inequality (INQ), inflation (INF)and unemployment (UMP) have significantly negative relationship with poverty reduction. This implies that an increase in any one or more of these variables can lead to a further increase in the incidence of poverty and hinder the achievement of the sustainable goal of poverty reduction in the long-run. While results of negative long-run relationship between poverty reduction and INQ, INF and UMP conform to economic theory and our a priori expectations, that between poverty reduction and PCI does not agree with a priori expectations. However, this goes a long way to show that the outcomes of all economic activities from the industrial sector are more beneficial to the rich than the poor who, incidentally, are in the majority. Although the result also revealed that growth from the service sector was found to have positive relationship with poverty reduction in the long-run, the result is, however, not significant. This study is aimed at investigating the impacts of pattern of growth and socioeconomic variables on poverty reduction in Nigeria. This is with a view to providing empirical tool for identifying the variable(s) that can drive poverty alleviation or reduction in the economy. Towards this goal, the study found from the results that growth in PCA and/or reduction in INQ has the highest potentials of achieving poverty reduction in Nigeria. This result is not surprising because it finds support in the fact that majority of Nigerians are rural dwellers whose main enterprise is farming and all agriculture related business. Incidentally, this group of people is majorly poor in the economy. Growth from this sector is expected to result from increase in economic activities for the poor, which consequently leads to improvement in their income and, hence reduction in poverty.

A further consideration of the results for the short-run relationship between the variables of study also reveals that the lagged values of poverty reduction, pattern of growth, inequality, inflation, unemployment and human capital development have significant impact on poverty reduction for the present period. This implies that the success of the current efforts aimed at reducing or alleviating poverty depend significantly on the previous attempts made at reducing poverty, inequality, inflation, unemployment and improvement in human capital development.

All the results for both the long-run and short-run relationships between the variables of study, with the exception of growth emanating from the industrial sector (PCI), were found to be consistent with economic theory and the study's priori expectations. The results also conform to a similar study carried out on Brazil (Igor, 2016).

The short-run estimation results also show the error correction mechanism which measures the speed or degree of adjustment. This is the rate at which the dependent variable adjusts to changes inany of the independent variables. The coefficient of the ECT is found to be negative and statistically significant at the conventional level. The ECT value (2.325998) implied that in order to return to the long run equilibrium, it is of the opinion that the model corrects its shortrun disequilibrium by $233 \%$ speed of adjustment.

The coefficient of determination (Adjusted- $\mathrm{R}^{2}$ ) is high at 0.60041 , indicating that about $60 \%$ of the total variations in poverty reduction were explained by the variables in the model. The overall test using the F-statistic (3.833819) is statistically significant at $1 \%$ level of significance showing that the model is well specified and statistically significant.

\section{Conclusion and Recommendations}

Poverty reduction has continued to be of grave concern to successive governments in Nigeria since the introduction of SAP in 1985 to date. This is attested to by the prime position it occupies in the recently adopted SDGs by the Nigerian government. Although the Nigeria economy has grown significantly within the past two decades, contrary to the expectations of the policy makers, the growth has left little or no impact on reducing the incidence of poverty in Nigeria. Empirical evidences have, however, shown that growing the economy is necessary but not a sufficient condition to achieve poverty alleviation or reduction. The review of literature in this study has revealed that other factors like pattern of growth, inequality, unemployment and inflation also have the potentials of impacting on poverty reduction. This study, therefore investigated the impact of the pattern of growth and socioeconomic variables like inequality, inflation, unemployment and human capital on poverty reduction in Nigeria. The study applied the ARDL technique to estimate both the long-run and short-run relationship between the variables of study. The findings revealed that for both the longrun and short-run, growth in RGDP per capital emanating from agriculture (PCA) and industry (PCI) as well as inequality (INQ), inflation (INF), human capital (HC) and unemployment (UMP) have significant long-run relationship with poverty reduction at various levels of significant. Further to this, the short-run estimated results reveal that the lagged values of poverty reduction, pattern of growth, inequality, inflation, unemployment and human capital development have significant impact on poverty reduction for the present period. All the results, with the exception of growth emanating from the industrial sector (PCI), were found to be consistent with economic theory and the study's $a$ priori expectations. The results also conform to a similar study carried out on Brazil (Igor, 2016). On the basis of the findings of this study, it was concluded that even though all the variables have long-run and short-run relationship with poverty reduction in Nigeria, only the results for the variables PCA, PCI, INQ, INF, HC and UMP are statistically significant. Of all these variables that are statistically significant, growth in PCA and/or reduction in INQ have the highest potentials of achieving poverty 
reduction in Nigeria. Therefore, any policy formulation that is aimed at reducing poverty incidence in Nigeria must provide support to the agriculture sector and address the issue of income distribution.

The findings of the study have some important implications for the achievement of the SDGs relative to poverty reduction in Nigeria. Since one of the significance of this study is to provide policy makers with tools to achieving the goals of sustainable development, we present hereafter the policy recommendations from the findings of this study.

- The study from our ARDL model estimation revealed that for both the long-run and short-run, growth emanating from the agriculture sector (PCA) has a significantly strong potential poverty reduction.The study, therefore, recommended that the government should embark on policy measures such as the provision of training facilities, access to modern technology and easy access to loan facilities to the agricultural sector to enable the farmers, especially the majority rural farmers to add value to their products with a view to improving their earnings and consequently reduce their poverty level. Also the provisions of infrastructural facilities like good road network, cheap means of transportation and electricity can encourage most of the jobless youths in the cities to return to farming they left back in the village. This also will go a long way to reduce the general poverty level. It was also recommended that efforts should be made by the government to encourage the establishment of small scale enterprises (SMEs) and cottage industries to cater for the employment of those at the lower ladder of the income bracket. Also policies that encourage labour intensive industries, such as tax holidays and subsidies, should be embarked upon by the government to allow for absorption of more of the low-level labourers in the industrial sector. This will definitely make the sector more amenable to poverty reduction.

- We also found that the short-run and long-run coefficients of inequality (INQ) are significantly negative from our ARDL model, implying that the sector also has the potentials to impact on poverty reduction with an appropriate policy. The study, therefore, recommended that the government should employ the use of fiscal policies that place more taxes on some selected luxury commodities in order to finance pro-poor social services, thus freeing the poor of some resources that could be used for investment purposes. Provision of access to cheap loan and technical support to empower the small scale entrepreneurs (SMEs) can also help to reduce the income gap between the rich and the poor. The government should also prioritise the investment in infrastructural facilities like good road networks, cheap and affordable electricity and good means of transportation in the rural areas where most of the poor in Nigeria reside.

\section{References}

i. Adekoya, 0.0. (2018). Impact of human capital development on poverty alleviation in Nigeria. International Journal of Economics and Management Science.7(4), 1-8.

ii. Adelakun, O.J. Human capital development and economic growth in Nigeria. European Journal of Business Management, 3(9), 29-38.

iii. Anand, R.; Miahra, S. \&Peiris, S.J. (2013). Inclusive growth revisited: measurement and determinants of poverty reduction. Poverty Reduction and Economic management Network, 122, 1-7.

iv. Ayeni, A. O and Omobude, O.F. (2018). Educational expenditure and economic growth nexus in Nigeria (19872016). Journal of Advancement of Development Economics. 7(1), 59-77.

v. Becker, G.S. (1995). Human capital and poverty alleviation. Human Resources Development and Operations Policy. Work Paper 52.

vi. Central Bank of Nigeria (2019). Statisticalbulletin. Abuja; CBN Publications.

vii. Chikolu, J. C. (2016). Impact of human capital development on poverty alleviation in Nigeria.MRRA Paper. 74696, 1-6

viii. Christiansen, L. \&Kamiviski, J. (2015).Structural change, economic growth and poverty reduction: microeconomic evidence from Uganda. ADB Working Paper Series, 229, 1-55.

ix. Christiaensen, Luc, Lionel Demery, and JesperKuhl. (2010). The (Evolving) Role of Agriculture in Poverty Reduction: An Empirical Perspective. WIDER Working Paper, 36, UNU-WIDER, Helsinki.

X. Chuhan-Pole, P. (2014). How does the pattern of growth matter for poverty reduction in Africa?Africa's Pulse, (Fal), World Bank, Washington DC.

xi. Dursun, G \&Ogunleye, B. (2016). Economic growth, employment and poverty reduction: the case of West African countries. American Journal of Economics, 6(1), 50-60.

xii. Ebong, F.S. \&Ogwumike, F.O. (2013). Economic growth and poverty reduction in Nigeria: an empirical investigation. Journal of Economic and Sustainable Development, 4(7), 117-130.

xiii. Ewubare, D.B. \&Okpani, A.O. (2018).Poverty and income inequality in Nigeria.International Journal of Advanced Studies in Ecology, Development and sustainability. 5(1), 138-151

xiv. Ferreira, F.H.; Leite, P.G. \&Ravallion, M. (2007).Poverty reduction without economic growth?Explaining Brazil's poverty dynamics, 1985-2004.Policy Research Working Paper, WPS4431, 1-45.

xv. Gangas, S. (2017). Relationship between economic growth and poverty reduction in Nigeria.Journal of Business and Finance Management Research, 3(2), 24-56.

xvi. Hartwell, R. M. (1972). 'Consequences of the Industrial Revolution in England for the Poor.' In Ronald Max Hartwell (ed.), The Long Debate on Poverty. London: Institute of Economic Affairs.

xvii. Hill, R. V., and Tsehaye.H. (2014). Growth, Safety Nets and Poverty: Assessing Progress in Ethiopia from 1996 to 2011. Background paper for the Ethiopia Poverty Assessment, World Bank, Washington, DC.

xviii. Igor, B.M. (2016). Poverty reduction in Brazil: what is behind the decline during the 2000s? Retrieved March 12, 2020 from www.ehl.lu.se. 
xix. Ijaiya, J.T.; Ijaiya, M.A.; Bello, R.A. \&Ajayi, M.A. (2011).Economic growth and poverty reduction in Nigeria.International Journal of Business and Social Sciences, 2(15), 147-154.

xx. Kasali, T.A; Ahmad, S. A. and Lim, H. (2016), Microfinance and rural poverty alleviation: a reality? International Journal of Business and Society.17(3), 497-510.

xxi. Loayza, Norman V., and Claudio Raddatz. (2010). The Composition of Growth Matters for Poverty Alleviation. Journal of Development Economics 93 (1), 137-151.

xxii. Monash Business School. Retrieved March 31, fromwww.monash.edu/business/ma

xxiii. Montalvo, J.G. \&Ravallion, M. (2009).The pattern of growth and poverty reduction in China.Journal of Comparative Economics, 38(1), 2-16.

xxiv. National Bureau of Statistics (NBS), (2012).National poverty profile. Nigeria, National Bureau of Statistics.

xxv. NBS, (2016).Sustainable development goals indicators.Baselem Report.

xxvi. $\quad$ NBS, (2019).Statistical Bulletin, Section C final. Nigeria, National Bureau of Statistics.

xxvii. Obayori, J.B.; Udeorah, S. \&Aborh, K.B. (2018).Human capital investment and poverty reduction in Nigeria.International Journal of Research in Business, Economics and Management.2(1): 104-115.

xxviii. Ogbeide, E.N \&Agu, D.O. (2015). Poverty and income inequality in Nigeria: any causality? Asia Economic and Social Review, 5(3), 439-452.

xxix. Ogunleye, O.0., Owolabi, O.A., Sanyaolu, O.A. and Lawal, 0.0. (2018).Human capital development and economic growth in Nigeria.IJRD Journal of Business Management. 3(8), 17-37.

xxx. Olopade, B.C; Okodua, H; Oladosun, M \&Asaleye, A.J. (2019). Human capital and poverty reduction in OPEC member-countries. Retrieved April 3, 2020 from www.heliyon.com

xxxi. Ravallion, M. (2010).A Comparative Perspective on Poverty Reduction in Brazil, China and India.The World Bank Research Observer 26(1), 71-104

xxxii. Ravallion, M. (2016).Economics of poverty: history, measurement and policy. Oxford University Press, N.Y., USA.

xxxiii. Ravallion, M. \& Chen, S.(2007). China's uneven progress against poverty.Journal of Development Economics.82(1), $1-42$.

xxxiv. Ravallion, M \&Datt, G. (1996). How important to Indian's poor is the sectoral composition of economic growth? The World Bank Economic Review, 10(1), 1-25

xxxv. Schultz, T. W. (1981). Investing in People: The Economics of PopulationQuality. Berkeley and Los Angeles: University of California Press.

xxxvi. Sylvester, A.F. \&Obayori, J. (2018).Health care expenditure and economic growth in Nigeria.International Journal of Research innovations in social sciences.2(3), 33-36.

xxxvii. Ugwu, E. I. (2012). Economic growth and poverty in Nigeria: is growth pro-poor? Evidence from existing data set.MSc Thesis, University of Nigeria, Nssuka.

xxxviii. World Bank, (2014). Global Monitoring Report, 2014: Ending Poverty and Sharing Prosperity. Washington DC: World Bank.

xxxix. World Bank, (2019).World Development Indicators. Washington, DC: World Bank. http://data.worldbank.org/products/wdi 